The Same Thing Over and Over 



\section{The Same Thing Over and Over}

How School Reformers Get Stuck in Yesterday's Ideas

Frederick M. Hess 
Copyright $\odot 2010$ by the President and Fellows of Harvard College All rights reserved Printed in the United States of America Library of Congress Cataloging-in-Publication Data

Hess, Frederick M. The same thing over and over : how school reformers get stuck in yesterday's ideas / Frederick M. Hess.

p. $\mathrm{cm}$. Includes bibliographical references and index. ISBN 978-0-674-05582-7 (alk. paper) 1. School improvement programs-United States. 2. Educational change-United States. 3. Public schools-United States. 4. EducationAims and objectives-United States. 5. Education-

United States-Evaluation. I. Title.

LB2822.82.H492 2010 371.2'070973-dc22 2010013274 
FOR JOLEEN, WITH LOVE AND AFFECTION, FOR ALL YOUR SUPPORT 
